\title{
How Value Perception Affects Buying Intentions of Online Consumers?*
}

\author{
Hilal Özen** İsmail Kaya*** \\ Istanbul University İstanbul University
}

\begin{abstract}
This study tries to understand how Turkish online consumers perceive value for their purchase intentions. It develops a model in order to test the effect of value perception on buying intentions of those consumers. Besides, the model covers the effects of risk perception, quality perception, perceived sacrifice and perceived relative price on value perception. The model was applied to 1361 online consumers who bought technology products from online retailers in the last six months. Results confirmed that perceived relative price, perceived sacrifice and risk perception had a negative effect on value perception, but quality perception had a positive effect on value perception in online retailing. In addition, willingness to buy is positively influenced by value perception. Besides these, relative price perception and quality perception appear to have a stronger effect than risk perception and perceived sacrifice on consumers' value perceptions.
\end{abstract}

Keywords: Online marketing, value perception, Turkish consumers, Structural equation modeling.

\section{Değer Algılaması Online Tüketicilerin Satın Alma Niyetlerini Nasıl Etkiliyor?}

\section{Özet}

$\mathrm{Bu}$ çalışmada, online tüketicilerin satın alma niyetlerinde değer algılamasının nasıl bir rolü olduğu geliştirilen model doğrultusunda incelenmiştir. Ayrıca, algılanan risk, algılanan kalite, algılanan fedakârlık ve göreceli fiyat algılaması olarak belirlenen öncül değişkenlerin değer algılaması üzerindeki etkilerinin incelenmesi de çalışma kapsamında ele alınmıştır. Çalışma çerçevesinde geliştirilen araştırma modeli, son altı ay içerisinde online perakendecilerden teknolojik ürün satın almış olan 1361 tüketici üzerinde test edilmiştir. Elde edilen sonuçlar, göreceli fiyat algılaması, algılanan fedakârlık ve algılanan riskin değer algılamasını negatif yönde etkilerken, kalite algılamasının değer algılaması üzerinde pozitif yönlü bir etkisi olduğunu göstermiştir. Ancak, göreceli fiyat algılaması

\footnotetext{
* This study is derived from the doctoral dissertation of Hilal Özen entitled "Value Perception and Buying Intentions: A Comparison Between Traditional and Internet Shopping." The dissertation was funded by The Scientific and Technological Research Council of Turkey (TÜBİTAK) and Istanbul University Scientific Research Projects Unit.

** Hilal Özen is an Assistant Professor in the Faculty of Management at Istanbul University, 34322, Avc1lar, Istanbul, Turkey. E-mail: hilaloz@istanbul.edu.tr

*** İsmail Kaya is a Professor in the Faculty of Management at Istanbul University, 34322, Avc1lar, Istanbul, Turkey. E-mail: ikaya@istanbul.edu.tr
} 
ile algılanan kalitenin değer algılamasına olan etkilerinin diğer öncül değişkenlere oranla daha fazla olduğu görülmüştür. Bu sonuçlara ek olarak online perakendecilerden satın alma niyetinin, değer algılamasından olumlu yönde etkilendiği neticesine de ulaşılmıştır.

Anahtar kelimeler: Online pazarlama, değer algılaması, Türk tüketiciler, Yapısal Eşitlik Modeli.

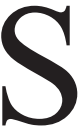

ince the Second World War, there have been two retail revolutions which have caused important changes in the history of retail; the first one was the mall concept and the second was the World Wide Web (Kim, 2002). Online shopping has become the fastest growing use of the Internet as a new way of shopping; the choices have increased for the consumers. Every day a new retailer enters the web. As more retailers go online, the competition in online retailing gets more complicated (Chen and Dubinsky, 2003). Besides, consumers have become increasingly more sophisticated and demanding in the availability of products, services and information online.

Convenience is the most known motivation for shopping online. A consumer has $7 / 24$ access to an online store, s/he can compare the offerings of sellers worldwide, and there are broader selection opportunities and greater access to information now (Ahn et al., 2004; Brynjolfsson and Smith, 2000; Kim, 2002). However, an online store cannot always be successful despite those advantageous features. It competes with other Internet shopping sites and also with traditional shopping channels. Thus, Internet stores need to better their understanding and prediction of consumers' online shopping behaviors to be competitive. Since customers are increasingly using the Internet for shopping purposes, it is assumed that some of them are also transferring their purchases from traditional stores to online retailers. If this change is to accelerate, customers should think that they get a better deal in online shopping than in traditional shopping.

For the postmodern consumer, the online shopping experience has become a central element of their lives, and consumption has become an act of experience production which is an expression of the self. For this reason, many retailers need to turn online shopping into a high-value pursuit and generate consumer value as an important source of competitive advantage (Lizhu, 2006).

As one of the important drivers of retail success is perceived value, this study mainly attempts to understand its effect on online buying intentions of Turkish consumers. Turkey was introduced to the Internet in 1993. From this year on, the Internet usage has grown tremendously. On the other hand, Turkish consumers' use of it for shopping is low.. According to the data of the Turkish Statistical Institute in 2011, $18.6 \%$ of Internet users bought goods or services from the Internet. The proportion was $15.0 \%$ in 2010. This ratio is not still satisfying compared to other countries in the world. But the progress shows promise considering that the proportion was only $5.59 \%$ in 2005 (TUIK, 2011). Besides the main purpose, the effects of risk perception, quality perception, perceived sacrifice and perceived relative price on value perception are also examined in the study. Thus, the purpose of this study is to identify the key drivers of value perception, and to examine the effect of value perception on the buying intentions of Turkish online consumers. 


\section{Conceptual Background and Hypotheses}

Before deciding to buy a service/product, consumers are affected by numerous factors. Chen and Dubinsky (2003) reported that much of the cognitive efforts relating to the purchase occur prior to actual buying behavior. So, e-tailers should know how to influence customers in their prepurchase stage. Value perception could be evaluated as a factor which affects the interests of consumers (Kotler and Keller, 2012: 580), and this interest may direct the consumers to consider buying a service or product. According to many studies, perceived value has been found as an important predictor of willingness to buy (Baker, 1990; Dodds and Monroe, 1985; Dodds et al., 1991; Sweeney, 1995; Sweeney et al., 1999).

The model as illustrated in Figure 1 shows the key factors which influence value perception in an online retail setting. The core variable is perceived value. Several antecedents and willingness to buy as an outcome are also included in the model. A set of hypotheses was developed based on a review of conceptual background.

Figure 1:

The Conceptual Model and Hypotheses

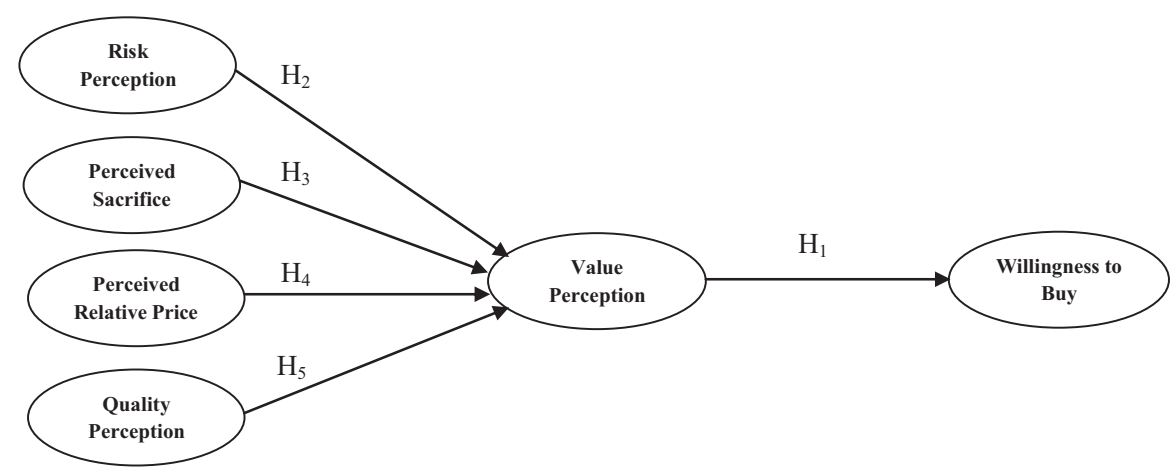

\section{Value Perception}

This study's framework is based on perceived value, its antecedents and its consequence. Perceived value has gained much attention from marketers and researchers because of the important role it plays in predicting purchase behavior and achieving a sustainable competitive advantage (Chen and Dubinsky, 2003).

Before addressing the role of value perception on consumer's channel selection behavior, it is believed that making a broad definition about perceived value will be appropriate. According to Sinha and DeSarbo (1998: 237), "value is central to economic exchange and endemic to marketing, in which both the buyer and seller obtain a value greater than each gives up." Thus both parties are economically gainers because each receives something more useful to him/her than what he/she has given up. If both of the parties believe that they make a profit from a transaction, they will think that the transaction has a value for them. 
Numerous studies have been conducted in marketing to understand the concept of perceived value. One of the pioneering studies in this field was made by Zeithaml in 1988. In her exploratory study, people were asked to define what they understood from value perception. Their expressions about perceived value were conceptualized in one overall definition: "Perceived value is the consumer's overall assessment of the utility of a product based on perceptions of what is received and what is given." Zeithaml's definition provides a basis for most of the studies made about perceived value in the literature. This definition of perceived value involves a trade-off between what a customer receives and what he/she gives up to acquire a product or service (Tam, 2004). Based on previous definitions, this study defines perceived value as "consumers' perceptions of net benefits in which they endure for the costs in order to get the benefits from an online transaction."

Different customers may view the value of the same Internet purchase very differently. This is so even if they value the purchased item identically. One may experience difficulties and find it buying over the Internet impersonal, whereas another may find it more convenient. In addition to all the options, different consumers could consider different benefits and costs in evaluating the net value of prospective Internet purchases (Keeney, 1999: 534). Due to different levels of value perceptions, consumers will differ in their buying decisions. As stated before, value perception is a predictor of consumers' buying intentions. Value perceptions of online consumers are expected to have a positive effect on their willingness to buy.

$\mathbf{H}_{1}$ : Value perception is positively associated with willingness to buy.

\section{Risk Perception}

Risk perception has become the major area of research in consumer behavior research. According to Mitchell (1999: 163), this is because perceived risk is more powerful in explaining consumers' behavior and because customers are more often motivated to refrain from mistakes than to maximize utility in their buying decisions. According to Solomon, perceived risk is the belief that there might be negative consequences from using a service or product (Solomon, 2011: 345). In another description, risk perception is defined as the "subjective expectation of a loss" (Sweeney et al., 1999: 81). When the customer is more certain about this expectation, the risk for the individual will be greater (Mitchell, 1999: 168). Consumers often come up with the dilemma of wanting to purchase a product, but they are uncertain about buying because that involves risking suffering some type of loss (Roselius, 1971: 56). In an online retail setting, this dilemma is getting stronger. As Solomon and others (2006: 541) stated: "an unknown is accompanied by high perceived risk," and in online retailing this obscurity occurs often because before buying a product, consumers want to touch, taste, and/or smell, in other words experience a product. They want to perceive as little risk as possible. According to Geert Hofstede's (2012) study Turkish people's risk avoidance coefficient is 85 , which is a high rate. So it can be said that Turkish consumers want to buy the products by seeing, touching or tasting as much as is possible (Koç, 2007). The inclusion of perceived risk in a value model may help to explain how perceived value is evaluated in an online retail setting. 
This study includes two risk dimensions: financial and performance risk. Each risk dimension can be viewed as an expectation of a future cost that contributes to a good's perceived value relative to the money at the time of purchase. Financial risk is defined as a net financial loss to a customer, including the possibility that the product may need to be repaired, replaced or the purchase price refunded. Performance risk is defined as the loss incurred when a brand or product does not perform as expected. These two dimensions were found to be the strongest ones in the literature relating to the risk perception (Agarwal and Teas, 2001; Bearden and Shimp, 1982; Sweeney et al., 1999). Similarly, the most significant results for risk perception in online shopping were the same dimensions (Bhatnagar and Ghose, 2004; Bhatnagar et al., 2000; Forsythe et al., 2006). Several studies suggest that perceived risk negatively impacts perceived value (Agarwal and Teas, 2001; Chen and Dubinsky, 2003; Snoj et al., 2004; Sweeney et al., 1999). In this study it is expected that perceived risk has a negative effect on value perception.

$\mathbf{H}_{2}$ : Risk perception is negatively associated with value perception.

\section{Perceived Sacrifice}

Sacrifice is defined by Cronin et al. (2000: 201) as what is given up or sacrificed to acquire a product or service. According to $\mathrm{Chu}$ and $\mathrm{Lu}(2007: 141)$ in the consumption decision process, price is what a customer pays in money terms to obtain a product or service. Therefore, price is often used as the key measure to represent what customers have to sacrifice to gain this product or service. But, items that represent consumers' perceptions of the monetary and the non-monetary price associated with the acquisition and use of a service or product are the indicators of the sacrifice construct. Zeithaml (1988: 17) states that sacrifice should not be limited to monetary price alone, especially in situations where time costs, search costs, and convenience costs are important to the consumer. According to some consumers, the monetary sacrifice is important, so they will invest hours in order to obtain the best prices. To these consumers, anything that reduces the monetary sacrifice will increase the perceived value of the product. In contrast to those types of consumers, some other consumers find value in readyto-serve food products, store proximity, and home delivery to be the deciding factors. Even at the expense of higher costs, they are ready to pay because they perceive time and effort more costly.

When making decisions with regard to buying a product or service online, the online consumers also certainly consider both monetary and non-monetary costs. In this context, perceived sacrifice includes all the costs (acquisition costs, time, effort) that a consumer faces during an online purchase process (Ravald and Grönroos, 1996). Value perception is negatively affected by perceived sacrifice (Chu and Lu, 2007; Lin, 2003).

$\mathbf{H}_{3}$ : Perceived sacrifice is negatively associated with value perception.

\section{Perceived Relative Price}

Perceived relative price is defined in terms of "consumers' perceptions of the price compared to other brands of the same product with similar features" which is obviously different from the actual price of the product (Swait and Sweeney, 2000: 81). In 
the same manner perceived relative price of a shopping channel can be defined as the price of that channel compared to alternative shopping channels. Sweeney, Soutar and Johnson (1999: 88) argue that the importance of price to perceived value for money in a retail situation is likely to be derived from comparing the price of the given brand with brands of similar products or services with the same features. For this reason, perceived relative price was considered more significant for the buying decision than any dollar metric (Sirohi et al., 1998; Swait and Sweeney, 2000; Sweeney et al., 1999). Studies in the literature found a negative relationship between perceived relative price and value perception (Sirohi et al., 1998; Swait and Sweeney, 2000; Sweeney et al., 1999). So it is hypothesized that:

$\mathbf{H}_{4}$ : Perceived relative price is negatively associated with value perception.

\section{Quality Perception}

Perceived product quality is defined as the "consumer's judgment about a product's overall superiority" (Chen and Dubinsky, 2003: 330). In the same manner, this study defines the perceived quality of an online retailer as the perceived excellence of the products or services sold in this channel. Perceived quality is different from objective quality in which the same logic is processed with perceived relative price. Objective quality is the term used in the literature to describe the actual technical superiority or excellence of the products or services (Zeithaml, 1988: 4). But perceived quality is different from objective quality. Perceived quality is defined as "consumers' assessment regarding the global excellence or superiority of a product" (Zeithaml, 1988). Perceived quality consists of intrinsic and extrinsic cues. Physical features are the color, flavor, and texture of products. Extrinsic cues are product-related but not part of the physical product itself such as brand, advertising, and image (Chu and Lu, 2007). This study tries to expose the perceived quality of the online shopping channel by measuring the consumers' quality perceptions of the products sold in this channel, and defines quality perception as the customer's overall quality perceptions of the merchandise provided by the online retailer. Researchers have found that perceived quality has a positive effect on perceived value perception (Baker et al., 2002; Cronin et al., 2000; Sirohi et al., 1998). As a result following hypothesis is proposed:

$\mathbf{H}_{5}$ : Quality perception is positively associated with value perception.

\section{Research Methodology}

\section{Research Objectives}

This study tries to investigate consumers' perceptions of buying technology products online. This product group is selected because they are often sold through the Internet. Technology products have the highest turnover rates in online retailing channels in Turkey (Alışveriş Merkezleri ve Perakendeciler Derneği-AMPD, 2008; CNN Türk News Site, 2011). Furthermore, technology products in Turkey are widely sold from Internet stores as well as from traditional stores. In particular, firms like Teknosa, Bimeks, Gold, Darty, Istanbul Bilişim, and Vatan use both channels to sell technology products. 
The objectives of the present research are to address two questions: (1) Do value perceptions of online consumers affect their willingness to buy? (2) What kind of effects have the antecedents of value perception on willingness? Those issues are addressed with a large and representative Turkish Internet population for the sample in the study.

\section{Sample}

In order to test the hypothesized model an online survey was conducted. The sample of the survey was made up of consumers who had bought a technology product from an Internet retailer in the last six months. This product group was selected because they are often sold through the Internet stores, and because technology products have the highest turnover rates in online channels in Turkey (CNN Türk News Web Site, 2011).

The survey was conducted from February 9 to 25, 2011. A well-known electronic company provided a sample of consumers who had purchased a technology product using their web site at least once. An e-mail was sent to the consumers in order to announce the survey. The e-mail address of the electronic company was used as the sending address to evoke feelings of familiarity and to reduce privacy concerns. The consumers were requested to submit the questionnaire. The e-mail sent contained the purpose of the questionnaire, the length of the questionnaire and the incentive that would reward returning the questionnaire. The company had guaranteed that the data would be treated confidentially. A link to the address was provided with instructions to start the questionnaire, and 1720 people submitted the online survey, of which 1361 provided usable answers for the study.

The demographic characteristics of the survey sample is summarized in Table 1 . The sample was comprised of 101 (7.4\%) women and 1260 men (92.6\%). The respondents' ages ranged from 18 to over 58 years. Most of the respondents were between the ages of 26-33 (32.1\%); they were followed by the ages of 18-25 (23.8\%). High school and lower grade respondents comprised $17.3 \%$, while university and higher respondents were $82.7 \%$ of the sample.

Table 1

\section{Demographic Characteristics of the Sample}

\begin{tabular}{l|l|l|l|l|l|l|l|l}
\hline Age & $\mathbf{n}$ & $\mathbf{\%}$ & Education & $\mathbf{n}$ & $\mathbf{\%}$ & Gender & $\mathbf{n}$ & $\mathbf{\%}$ \\
\hline $18-25$ & 324 & 23.8 & Have not completed High School & 27 & 2.0 & Female & 101 & 7.4 \\
\hline $26-33$ & 437 & 32.1 & High School & 208 & 15.3 & Male & 1260 & 92.6 \\
\hline $34-41$ & 308 & 22.6 & University & 943 & 69.3 & Total & 1361 & 100.0 \\
\hline $42-49$ & 171 & 12.6 & MS/Doctorate & 183 & 13.4 & & & \\
\hline $50-57$ & 92 & 6.8 & Total & 1361 & 100.0 & & & \\
\hline $58+$ & 29 & 2.1 & & & & & & \\
\hline Total & 1361 & 100.0 & & & & & & \\
\hline
\end{tabular}




\section{Measures}

The items which were used in this study were generated from a literature review. Overall value perception scale was adapted from Duman (2002) and has five items. Antecedents of perceived value which were risk perception, perceived sacrifice, perceived relative price and quality perception were measured by 18 items in total. Perceived risk is composed of financial risk and performance risk and had seven items. It was derived from Sweeney et al.(1999), Stone and Gronhaug (1993) and Broekhuizen (2006). Perceived sacrifice was measured by four items and was adapted from Cronin, Brady and Hult (2000). Perceived relative price had three items (Baker et al., 2002; Sirohi et al., 1998; Sweeney et al., 1999). Finally, quality perception was measured with four items and was based on Dodds et al.'s (1991) and Broekhuizen's (2006) scale. All of the items were assessed via a five-point Likert-type scale ranging from "strongly disagree" (1) to "strongly agree" (5). All of the measurement items can be found in the appendix Table A1.

\section{Method of Analysis}

Structural equation modeling (SEM) was chosen for the analysis because of its appropriateness to the research model. A two-stage analysis method, measurement model and structural model, was used for data analysis. In the measurement model, latent variables are explained by their observed variables. In the structural model, relationships between the latent variables are modelled. The structural model captures the regression effects of independent variables on dependent variables, and the regression effects of dependent variables on each other (Farag et al., 2007: 132). AMOS was used to perform those analyses.

\section{Assessment of the Measurement Model}

Before analyzing the structural model, the validity and reliability of the constructs were tested. Confirmatory factor analysis (CFA) was analyzed to ensure the validity of the constructs. The purpose of testing the CFA model was to reach acceptable levels of discriminant and convergent validities of the constructs. These two types of validity are often used to assess construct validity (Broekhuizen, 2006). Construct validity is the extent to which a set of measured items actually reflects the theoretical latent construct that those items are designed to measure (Hair et al., 2010: 708).

Table 2

Goodness of Fit Results for Measurement Model

\begin{tabular}{l|l|l|l|l|l|l}
\hline & $\mathbf{X}^{2} / \mathbf{s d}$ & GFI & AGFI & CFI & NFI & RMSEA \\
\hline Goodness of Fit Measures & 3.79 & 0.939 & 0.921 & 0.971 & 0.961 & 0.045 \\
\hline Recommended Levels & $<3.00$ & $>0.90$ & $>0.90$ & $>0.90$ & $>0.90$ & $<0.08$ \\
\hline
\end{tabular}

The goodness of fit results of CFA are given in Table 2. The fit of the CFA model are assessed on a number of fit indices including relative chi square, goodness of fit (GFI), adjusted goodness of fit index (AGFI), comparative fit index (CFI), normed fit index (NFI), and Root Mean Square of Approximation (RMSEA) (Hair et al., 2010; Kline, 2005; Raykov and Marcoulides, 2006). 
The chi-square statistics was found significant, and the ratio of the chi square value relative to degrees of freedom was more than the cutoff point of 3 . However, this is because of the large sample size. The goodness of fit index (GFI), adjusted goodness of fit index (AGFI), normed fit index (NFI), and comparative-fit index (CFI) were all greater than the recommended 0.9 ; and the root mean square error of approximation (RMSEA) was less than 0.08 (Hair et al., 2010). Overall, the measurement model represents a good fit with the data.

Table 3

Standardized Parameter Estimates of the Observed Indicators for the Latent Variables

\begin{tabular}{|c|c|c|c|}
\hline Construct & Item & Factor Loading & $t$-value \\
\hline \multirow[t]{4}{*}{ Financial Risk Perception } & FRP1 & $0.604^{\mathrm{b}}$ & 21.087 \\
\hline & FRP2 & $0.628^{\mathrm{b}}$ & 22.007 \\
\hline & FRP3 & $0.778^{\mathrm{a}, \mathrm{b}}$ & \\
\hline & FRP4 & $0.765^{\mathrm{b}}$ & 27.396 \\
\hline \multirow[t]{3}{*}{ Performance Risk Perception } & PRP1 & $0.807^{\mathrm{b}}$ & 32.579 \\
\hline & PRP2 & $0.834^{\mathrm{b}}$ & 33.795 \\
\hline & PRP3 & $0.827^{\mathrm{a}, \mathrm{b}}$ & \\
\hline \multirow[t]{4}{*}{ Perceived Sacrifice } & PS1 & $0.505^{\mathrm{b}}$ & 16.19 \\
\hline & PS2 & $0.752^{\mathrm{b}}$ & 26.068 \\
\hline & PS3 & $0.823^{\mathrm{b}}$ & 28.814 \\
\hline & PS4 & $0.925^{\mathrm{a}, \mathrm{b}}$ & \\
\hline \multirow[t]{3}{*}{ Perceived Relative Price } & PRPr1 & $0.840^{\mathrm{b}}$ & 34.664 \\
\hline & PRPr2 & $0.804^{\mathrm{b}}$ & 33.091 \\
\hline & PRPr3 & $0.846^{\mathrm{a}, \mathrm{b}}$ & \\
\hline \multirow[t]{4}{*}{ Quality Perception } & QP1 & $0.881^{\mathrm{b}}$ & 37.607 \\
\hline & QP2 & $0.943^{\mathrm{b}}$ & 51.014 \\
\hline & QP3 & $0.955^{\mathrm{a}, \mathrm{b}}$ & \\
\hline & QP4 & $0.804^{\mathrm{b}}$ & 39.114 \\
\hline \multirow[t]{5}{*}{ Value Perception } & VP1 & $0.874^{\mathrm{b}}$ & 30.753 \\
\hline & VP2 & $0.832^{\mathrm{b}}$ & 30.164 \\
\hline & VP3 & $0.846^{\mathrm{b}}$ & 29.923 \\
\hline & VP4 & $0.852^{\mathrm{b}}$ & 35.247 \\
\hline & VP5 & $0.870^{\mathrm{a}, \mathrm{b}}$ & \\
\hline \multirow[t]{4}{*}{ Willingness to Buy } & WTB1 & $0.885^{\mathrm{a}, \mathrm{b}}$ & \\
\hline & WTB2 & $0.875^{\mathrm{b}}$ & 45.184 \\
\hline & WTB3 & $0.899^{\mathrm{b}}$ & 47.661 \\
\hline & WTB4 & $0.814^{b}$ & 39.355 \\
\hline
\end{tabular}

${ }^{a}$ Item fixed on 1.00 .

${ }^{b}$ Significance at the 001 level. 
This study has also tested the convergent validities of the constructs according to Fornell and Larcker (1981). They evaluated convergent validity according to the significances of the factor loadings. All of the factor loadings were significant and all were greater than 0.60 , except perceived sacrifice 1 (see Table 3). Also, reliability is an indicator of convergent validity. Coefficient alpha is a commonly applied estimate although it may understate reliability. Different reliability coefficients do not cause dramatically different reliability estimates, but a slightly different construct reliability (CR) value is often used in conjuction with SEM models. The rule is again the same logic as the other reliability estimates, in which a 0.70 or higher coefficient suggest good reliability (Hair et al., 2010: 709). In this study all of the reliability coefficients are as required (see Table 4 ).

Table 4

Correlation Matrix

\begin{tabular}{l|l|l|l|l|l|l|l|l}
\hline & $\mathbf{( 1 )}$ & $\mathbf{( 2 )}$ & $\mathbf{( 3 )}$ & $\mathbf{( 4 )}$ & $\mathbf{( 5 )}$ & $\mathbf{( 6 )}$ & AVE & $\begin{array}{l}\text { CR } \\
\text { (Construct } \\
\text { Reliability) }\end{array}$ \\
\hline (1) Willingness to Buy & $\mathbf{0 . 8 6 9}$ & & & & & & $0.755^{\text {a }}$ & 0.925 \\
\hline (2) Risk Perception & -0.463 & $\mathbf{0 . 9 5 2}$ & & & & & $0.907^{\text {a }}$ & 0.951 \\
\hline (3) Perceived Sacrifice & -0.321 & 0.606 & $\mathbf{0 . 7 6 7}$ & & & & $0.588^{\text {a }}$ & 0.846 \\
\hline (4) Perceived Relative Price & -0.539 & 0.344 & 0.287 & $\mathbf{0 . 8 3 0}$ & & & $0.689^{\text {a }}$ & 0.869 \\
\hline (5) Quality Perception & 0.454 & -0.460 & -0.271 & -0.451 & $\mathbf{0 . 8 9 8}$ & & $0.806^{\text {a }}$ & 0.943 \\
\hline (6) Value Perception & 0.675 & -0.541 & -0.397 & -0.638 & 0.638 & $\mathbf{0 . 8 5 5}$ & $0.731^{\text {a }}$ & 0.931 \\
\hline${ }^{a} A V E>0.5$.
\end{tabular}

Discriminant validity was also used in order to test construct validity. Malhotra (2010) describes discriminant validity as the extent to which a measure does not correlate with other constructs from which it is supposed to differ. Testing for discriminant validity could be done using one of the following methods: Q-sorting, chi-square difference test and the average variance extracted analysis (Zait and Bertea, 2011). The use of average variance extracted (AVE) is recommended; it should be greater than the variances shared between the constructs. The comparison is usually made in a correlation matrix (Liu et al., 2012). With regard to the local fit of the CFA model, all constructs in the model have an average variance extracted greater than the acceptable level of 0.50 as shown in Table 4 (Hennig-Thurau et al., 2004). An AVE of 0.50 or higher is a good rule of thumb suggesting adequate convergence (Hair et al., 2010). The discriminant validity exists between two constructs if the AVE of both constructs is greater than the variance shared by the two (Hennig-Thurau et al., 2004). The results in Table 4 also indicate that all of the constructs had an adequate discriminant validity. 


\section{Structural Model}

In order to test the hypotheses of the proposed model, structural equation modeling is used. The overall fit of the hypothesized model was good. For the data collected, the results obtained were: $\mathrm{X}^{2}: 1115.734$, df:288, X²/df:3.87, GFI:0.940, AGFI:0.921, CFI:0.971 and RMSEA:0.046. The proposed model explains $47.8 \%$ of the variance of the willingness to buy construct. In Table 5, the results of the parameter estimates for the online dataset are reported. All structural regression coefficients presented in the model were statistically significant. The path from value perception to willingness to buy $\left(\mathrm{H}_{1}\right)$ was significantly supported. The negative relationships between risk perception and value perception $\left(\mathrm{H}_{2}\right)$, perceived sacrifice and value perception $\left(\mathrm{H}_{3}\right)$, and perceived relative price and value perception $\left(\mathrm{H}_{4}\right)$ were all supported. Also the path from quality perception to value perception $\left(\mathrm{H}_{5}\right)$ was found statistically significant for the online sample (see Table 5).

Table 5

Structural Parameter Estimates

\begin{tabular}{l|l|l|l}
\hline & Parameter Estimates & $t$-values & Hypothesis \\
\hline Value Perception $\rightarrow$ Willingness to Buy & 0.825 & $24.833^{*}$ & Supported \\
\hline Risk Perception $\rightarrow$ Value Perception & -0.215 & $-7.026^{*}$ & Supported \\
\hline Perceived Sacrifice $\rightarrow$ Value Perception & -0.061 & $-2.710^{*}$ & Supported \\
\hline Perceived Relative Price $\rightarrow$ Value Perception & -0.326 & $-15.796^{*}$ & Supported \\
\hline Quality Perception $\rightarrow$ Value Perception & 0.315 & $14.840^{*}$ & Supported \\
\hline${ }^{*} p<0.05$ & \multicolumn{3}{l}{}
\end{tabular}

According to the standardized regression coefficients shown in Table 6, value perceptions of online consumers have a positive and strong effect on their willingess to buy technology products from online retailers. The online consumers' risk perceptions and relative price perceptions have a moderate and negative effect on their value perceptions. But sacrifice perception has a negative and weak effect on value perception. The quality perceptions of online consumers have a positive and moderate effect on their value perceptions.

Table 6

Standardized Regression Coefficients

\begin{tabular}{l|l}
\hline & Parameter Estimates \\
\hline Value Perception $\rightarrow$ Willingness to Buy & 0.691 \\
\hline Risk Perception $\rightarrow$ Value Perception & -0.208 \\
\hline Perceived Sacrifice $\rightarrow$ Value Perception & -0.069 \\
\hline Perceived Relative Price $\rightarrow$ Value Perception & -0.391 \\
\hline Quality Perception $\rightarrow$ Value Perception & 0.360 \\
\hline
\end{tabular}




\section{Conclusion}

This study examined Turkish consumers' buying intentions of technology products from e-tailers by building a structural equation model. Due to focusing on technology products, the customers of a well-known electronic company participated in the online survey. It contributed to the understanding of antecedents of value perceptions for consumers surveyed online. Based on evidence from previous research, this study identified four antecedents. These antecedents were risk perception, perceived sacrifice, perceived relative price and quality perception.

First of all, the validity and reliability of the constructs were examined. The results indicate that all the constructs which were value perception, risk perception, perceived sacrifice, perceived relative price, quality perception and willingness to buy have both convergent and discriminant validity. The structural model also fits well with the data. The proposed model was strongly supported by the data collected by an online survey in Turkey. The relationships between antecedents, value perception and willingness to buy were explored. The results are helpful in understanding the impact of value perception on buying intentions in the online environment where technology products are sold.

Value perception was found as a predictor for buying intentions of consumers in the past (Chen and Dubinsky, 2003; Cronin et al., 2000; Cronin et al., 1997; Turel et al., 2007). This study also confirms the positive relationship between value perception and willingness to buy $\left(\mathrm{H}_{1}\right)$. Consumers think that using e-tailers for shopping is a good value for them; they are more willing to use this channel than traditional channels.

Risk perception $\left(\mathrm{H}_{2}\right)$, perceived sacrifice $\left(\mathrm{H}_{3}\right)$ and perceived relative price $\left(\mathrm{H}_{4}\right)$ are found to have negative impacts on value perception. Those findings were supported by previous studies both offline (Agarwal and Teas, 2001; Snoj et al., 2004; Teas and Agarwal, 2000) and online (Broekhuizen, 2006; Chen and Dubinsky, 2003) environment. This means that in an online shopping environment striving to reduce the consumers' risk perceptions, sacrifice perceptions and relative price perceptions are all of significance in increasing their value perceptions.

When the consumers see the online store as risky and when they think that the effort they make and the time required is high, their value perceptions decrease. If consumers think that the e-store offers low prices and has attractive offers they see this channel more valuable. The magnitude of the effects that these factors have on value perception are all similar, with perceived sacrifice slightly lower than risk perception and perceived relative price. Compared with perceived sacrifice and risk perception, the perceived relative price's negative effect is higher $(-0.391)$. This means that, after making comparisons with other stores, if the consumer realizes the e-store has higher prices, s/he evaluates the store low in value. This evaluation possibly will negatively affect her/his willingness to buy. Therefore it is clear that price competition in the Internet is still an important factor in Turkey and causes fierce competition. 
Similar to the literature reports (Broekhuizen, 2006; Hellier et al., 2003), quality perception was found to affect value perception positively $\left(\mathrm{H}_{5}\right)$. If the consumer finds the products sold in an online technology retailer durable, dependable and reliable his/ her value perception regarding to this e-tailer will be high. Generally said, when the consumers perceive that the quality of the merchandise sold by an e-tailer as high, they perceive the online channel more valuable.

\section{Discussion and Implications}

According to the results, this study confirms that while shopping from online stores, the consumers evaluate the e-tailers not only from risk or price aspects. They also consider the sacrifices they make, the quality of the products they buy and also the relative price they perceive compared to that of traditional stores. The results indicate that all concerns for lower risk, relative price, sacrifice and higher quality serve to increase value perceptions of online consumers which cause a higher willingness to buy.

Relative price perception and quality perception appear to have stronger effect than risk perception and perceived sacrifice on consumers' value perceptions. This means that not only e-stores with lower prices can survive, but also e-stores having high quality products can survive the competition.

The most interesting finding of this study was the higher negative effect of perceived relative price on value perception when compared to negative effects of risk perception and perceived sacrifice. This indicates that the Turkish consumers who participated the survey are not only quality conscious, but also price conscious in shopping with online electronic retailers. In a survey conducted by Sweeney, Soutar and Johnson (1999), performed with Australian consumers buying electrical appliances from a traditional retail setting, it was found that perceived risk had a more powerful, direct effect on perceived value than the perceived relative price. This finding is different from our study in two aspects. The first difference could be that the study was held in a traditional context, and secondly it was conducted in Australia. In Turkey, the reason for the difference is thought to be mainly because of the channel. In the online context, especially after the daily deal sites which have become popular in Turkey started to compete in the market over the last two years, people use this channel still for buying products for lower prices. Also, e-tailers selling technology products in Turkey emphasize the "relative lower price" factor in their campaigns. This shows that, putting forward "lower prices" still works in Turkish online retailing.

In Turkey, online sales in 2010 generated $\$ 13$ billion annual sales volume, whereas this number is $\$ 200$ billion in the US. This indicates that e-commerce is still at the introductory stage in Turkey (Özen and Kodaz, 2012). Also, recent results from the Turkish Statistical Institute's ICT (Information Communications Technology) Usage in Households Survey (2012) show that in Turkey 21.8\% of internet consumers used the Internet for shopping, which is still low when compared to other developed countries. As indicated before, the Turkish population is a risk averse society. The underlying reason for people not doing much online shopping maybe mostly because of their risk avoidance. 
Because of the negative relation between risk perception and value perception, online shopping should be made more familiar to Turkish people. For instance user friendly web sites allowing people to feel themselves more safe in this channel could be a way to get them used to online shopping. In addition to the financial risks, online retailers are perceived risky when it comes to the performances of their products. The consumers still doubt that the product they will receive will perform well. The performance perception of the products sold online needs to be improved. Online retailers might provide their consumers with the opportunity of getting advice from other consumers who are shopping at the same time as they are or who already bought the same product. Those people who are planning to buy products could share their experiences with each other and this could reduce their performance risk perceptions. Since people in Turkey are collectivist in nature, they respect and also give importance to the ideas of others. The suggestions of other people will help them reduce their risk perceptions.

On the other hand, the sacrifice component has also a significant but a negative weak effect on value perceptions for Turkish online consumers in the study. Other studies in the literature found different findings. The study held by Cronin, Brady and Hult (2000) found no relationship between perceived sacrifice and value perception in the service industry. But the research on consumers shopping from retailers held by Teas and Agarwal (2000) found a negative relationship between perceived sacrifice and value perception. In the same manner, Chapman and Wahlers (1999) found a negative relationship between consumers' perceived sacrifice and their value perceptions. In contrast with Teas and Agarwal (2000) and Chapman and Wahlers (1999), this study operationalized perceived sacrifice both as a monetary and nonmonetary sacrifice. The findings of the current study about sacrifice told us that when Turkish online consumers think that they are going to make some sacrifices (both monetary and nonmonetary) during buying products from online retailers, they will think this e-tailer is not worth the money spent. They do not want to spend more time, more money, more effort and also they do not want to get exhausted. Compared to traditional channels, in general the time and effort needed to do online shopping is relatively low. But since there are more than one alternative e-tailer, the speed of the websites becomes an important issue for the online consumers nowadays. They do not want to spend more time and effort even in making comparisons between products. Usually comparing products or comparing prices between different alternatives using the Internet is effortless and speedy, but pricing is an important factor for online consumers in Turkey. They do not want to perceive themselves as paying more money when shopping from online retailers. Again, they want to see lower prices in an e-tailer without wasting time and effort. But, when the factor loadings of the items are analyzed, the weight of nonmonetary items are higher compared to the monetary item in perceived sacrifice. So, online electronic retailers in Turkey could carefully follow their competitors' pricing strategies in order to respond rapidly to price changes, but they should also consider the importance of nonmonetary issues. They should follow the technological developments to improve the performance of their websites so that the consumers could search and buy the needed items without 
wasting time and effort. For example, in the US, according to the online survey fielded by Nielsen Online in $2007,81 \%$ of the respondents indicated that they use the Internet for its convenience while shopping. Only $46 \%$ listed low prices as the reason to shop online. This story is becoming also real for the Turkish e-markets because Turkey is not in the introductory position in the online shopping cycle any more.

\section{Limitations and Future Research}

The findings of this study could be viewed as an additional step in understanding online buying intentions of consumers. Despite the interesting findings and implications, this study has some limitations that may be overcome by further research. First, the results of this study are limited by Turkish consumers buying technology products from the Internet. For this reason, the generalizability of the findings with other product categories and services, for the whole population in Turkey should be made with care. Future research could use other products and services in order to extend the study. Also, future research could increase the number of participants by using random sampling. In this way the findings could be more generalizable.

Second, this study uses risk perception, quality perception, perceived sacrifice and perceived relative price as antecedents of value perception. Those factors are used in this study because of their conformity to the objectives and the product type selected. However some researchers in the literature used other antecedents of value perception in their studies such as country of origin, consumer experience and service quality (Agarwal and Teas, 2001; Broekhuizen, 2006; Chen and Dubinsky, 2003; Cronin et al., 2000; Sweeney et al., 1999; Teas and Agarwal, 2000). In the future, the other antecedents of value perception could be included and the effects retested.

Third, since, most of the studies (Kerin et al., 1992; Sweeney et al., 1999) in the past assume that perceived value is a unidimensional concept, this study measured overall value perception as unidimensional construct. In the literature, some studies had discussed its multidimensional nature. This approach conceives perceived value as a multidimensional construct that consists of several interrelated dimensions (Sheth et al., 1991; Sweeney and Soutar, 2001). Future research could improve this construct by using it as a multidimensional concept.

\section{References}

Agarwal, S. and Teas, R.K. (2001). "Perceived Value: Mediating Role of Perceived Risk," Journal of Marketing, 9(4): 1-14.

Ahn, T., Ryu, S. and Han, I. (2004). "The Impact of the Online and Offline Features on the User Acceptance of Internet Shopping Malls," Electronic Commerce Research and Applications, 3(4): 405-420.

Alışveriş Merkezleri ve Perakendeciler Derneği-AMPD (Shopping Centers and Retailers Association) (2009). "Perakende 250 Araştırma Raporu (Retailing 250 Research Report)." 
Baker, J.A. (1990). "The Effect of Retail Store Environments of Consumer Perceptions of Quality, Price and Value," Doctoral Dissertation, Texas A\&M University.

Baker, J.A., Parasuraman, D.G., and Voss, G.B. (2002). "The Influence of Multiple Store Environment Cues on Perceived Merchandise Value and Patronage Intentions," Journal of Marketing, 66: 120-141.

Bearden, W.O. and Shimp T.A. (1982). "The Use of Extrinsic Cues to Facilitate Product Adoption," Journal of Marketing Research, 19: 229-239.

Bhatnagar, A., Ghose S., and Raghav R.H. (2000). "On Risk, Convenience, and Internet Shopping Behavior," Communications of the ACM, 43(11): 98-105.

Bhatnagar, A. and Ghose, S. (2004). "Segmenting Consumers Based on the Benefits and Risks of Internet Shopping," Journal of Business Research, 57(12): 1352-1360.

Broekhuizen, T. (2006). Understanding Channel Purchase Intentions: Measuring Online and Offline Shopping Value Perceptions. Labyrinth Publications.

Brynjolfsson, E. and Smith, M. (2000). "Frictionless Commerce? A Comparison of Internet and Conventional Retailers," Management Science, 46: 563-585.

Chapman, J. and Wahlers, R. (1999). "A Revision and Empirical Test of the Extended Price-Perceived Quality Model," Journal of Marketing: Theory and Practice, 7(3): 53-64.

Chen, Z. and Dubinsky A.J. (2003). "A Conceptual Model of Perceived Customer Value in E-Commerce: A Preliminary Investigation," Psychology and Marketing, 20(4): 323-347.

Chu, C.W. and Lu, H.P. (2007). "Factors Influencing Online Music Purchase Intention in Taiwan: An Empirical Study Based on the Value-Intention Framework," Internet Research, 17(2): 139-155.

CNN Turk News Web Site. (2011), "Erkekler daha çok alışveriş yapıyor” (Men do more shopping). Available [online] at: http://www.cnnturk.com/2011/ekonomi/genel/01/25/erkekler.daha. cok.alisveris.yapiyor/604479.0/index.html (accessed 31 January, 2011).

Cronin, J.J., Brady, M.K., Brand, R.R., Hightower Jr, R., and Shemwell, D.J. (1997). "A CrossSectional Test of the Effect and Conceptualization of Service Value," Journal of Services Marketing, 11(6): 375-391.

Cronin, J.J., Brady, M.K., and Hult, G.T.M. (2000). "Assessing the Effects of Quality, Value, and Customer Satisfaction on Consumer Behavioral Intentions in Service Environments," Journal of Retailing, 76(2): 193-218.

Dodds, W.B., Monroe, K.B., and Grewal, D. (1991). "Effects of Price, Brand, and Store Information on Buyers' Product Evaluations," Journal of Marketing Research, 28(3): 307-319.

Dodds, W.B. and Monroe, K.B. (1985). "The Effect of Brand and Price Information on Product Evaluations," Advances in Consumer Research, 12: 85-90.

Duman, T. (2002). "A Model of Perceived Value for Leisure Travel Products.” Doctoral Dissertation, The Pennsylvania State University, The Graduate School College of Health and Human Development.

Farag, S., Schwanen, T., Dijst, M., and Faber, J. (2007). "Shopping Online and/or In-Store? A Structural Equation Model of the Relationships between E-Shopping and In-Store Shopping," Transportation Research Part A, 41: 125-141.

Fornell, C. and Larcker, D.F. (1981). "Evaluating Structural Equation Models with Unobservable Variables and Measurement Error," Journal of Marketing Research, 18(1): 39-50. 
Forsythe, S., Chuanlan, L., Shannon, D., and Gardner, L. C. (2006). "Development of a Scale to Measure the Perceived Benefits and Risks of Online Shopping," Journal of Interactive Marketing, 20(2): 55-75.

Hair, J.F., Black, W.C., Babin, B.J., and Anderson, R.E. (2010). Multivariate Data Analysis: A Global Perspective. New Jersey: Pearson Education Inc., Prentice Hall.

Hellier, P.K., Geursen, G.M., Carr, R.A., and Rickard, J.A. (2003). "Customer Repurchase Intention: A General Structural Equation Model," European Journal of Marketing, 37(11/12): 1762-1800.

Hennig-Thurau, T., Gwinner, K.P., Walsh, G., and Gremler, D.D. (2004). "Electronic Word-ofMouth via Consumer-Opinion Platforms: What Motivates Consumers to Articulate Themselves on the Internet?" Journal of Interactive Marketing, 18(1): 38-52.

Hofstede, G. (2012). "What About Turkey?” Available [online] at: http://geert-hofstede.com/turkey. html (accessed 10 February, 2012).

Keeney, R.L. (1999).“The Value of Internet Commerce to the Customer," Management Science, 45 (4): 533-542.

Kerin, R.A., Jain, A., and Howard, D.J. (1992). "Store Shopping Experience and Consumer PriceQuality-Value Perceptions," Journal of Retailing, 68(4): 376-397.

Kim, Y.K. (2002). "Consumer Value: an Application to Mall and Internet Shopping," International Journal of Retail \& Distribution Management, 30(12): 595-602.

Kline, R.B. (2005). Principles and Practices of Structural Equation Modeling. New York: The Guilford Press.

Koç, E. (2007). Tüketici Davranışı ve Pazarlama Stratejileri: Global ve Yerel Yaklaşım. (Consumer Behavior and Marketing Strategies: A Global and Local Approach). Seçkin Yayıncılık.

Kotler, P. and Keller, K.L. (2012). Marketing Management 14 E. Prentice Hall.

Lin, C.C. (2003). "A Critical Appraisal of Customer Satisfaction and E-Commerce," Managerial Auditing Journal, 18(3): 202-212.

Liu, C.L. (Eunice), Sinkovics, R.R., Pezderka, N., and Haghirian, P. (2012). "Determinants of Consumer Perceptions toward Mobile Advertising: A Comparison between Japan and Austria," Journal of Interactive Marketing, 26: 21-32

Lizhu, Y. (2006).“Cross-Shopping and Shopping Orientation Consumer Perceived Value in Today's Dynamic Retail Environment.” Doctoral Dissertation, The University of North Carolina.

Malhotra, N.K. (2010). Marketing Research: An Applied Orientation. New Jersey: Pearson Education Inc., Prentice Hall.

Mitchell, V.W. (1999). "Consumer Perceived Risk: Conceptualizations and Models," European Journal of Marketing, 33(1/2): 163-195.

Nielsen Online (2007). "Convenience, not Price, Drives Online Holiday Shopping, According to Nielsen Online Pre-Holiday Survey." Available [online] at: com/pr/pr_071120.pdf (accessed 27 February 2013).

Özen, H. and Kodaz, N. (2012). "Utilitarian or Hedonic? A Cross-Cultural Study in Online Shopping," Organizations and Markets in Emerging Economies, 3(2): 80-90.

Ravald, A. and Grönroos, C. (1996).“The Value Concept and Relationship Marketing," European Journal of Marketing, 30(2): 19-30. 
Raykov, T., and Marcoulides, G.A. (2006). A First Course in Structural Equation Modeling. New York: Psychology Press, Taylor and Francis Group.

Roselius, T. (1971). “Consumer Rankings of Risk Reduction Methods,” Journal of Marketing, 35: 56-61.

Sheth, J.N., Newman, B.I., and Gross, B.L. (1991). Consumption Values and Market Choices: Theory and Applications. Cincinnati, Ohio: South-Western Publishing Co.

Sinha, I., and DeSarbo, W.S. (1998). "An Integrated Approach toward the Spatial Modeling of Perceived Customer Value," Journal of Marketing Research, 35: 236-249.

Sirohi, N., McLaughlin, E.W., and Wittink, D.R. (1998). "A Model of Consumer Perceptions and Store Loyalty Intentions for a Supermarket Retailer,” Journal of Retailing, 74(2): 223-245.

Snoj, B., Korda, A.P. and Mumel, D. (2004). “The Relationships among Perceived Quality, Perceived Risk and Perceived Product Value," Journal of Product and Brand Management, 13(3): 156-167.

Solomon, M.R., Bamossy, G., Askegaard, S., and Hogg, M.K. (2006). Consumer Behaviour: A European Perspective. Prentice Hall Europe.

Solomon, M.R. (2011). Consumer Behavior: Buying, Having and Being. Pearson Global Edition.

Stone, R.N. and Gronhaug, K. (1993). "Perceived Risk: Further Considerations for the Marketing Discipline," European Journal of Marketing, 27(3): 39-50.

Swait, J. and Sweeney, J.C. (2000). "Perceived Value and Its Impact on Choice Behavior in a Retail Setting," Journal of Retailing and Consumer Services, 7: 77-88.

Sweeney, J.C. (1995). "An Investigation of a Theoretical Model of Consumer Perceptions of Value." Doctoral Dissertation, School of Management and Marketing, Curtain University of Technology, Perth, Australia.

Sweeney, J.C. and Soutar, G.N. (2001). "Consumer Perceived Value: The Development of a Multiple Item Scale," Journal of Retailing, 77: 203-220.

Sweeney, J.C., Soutar, G.N. and Johnson, L.W. (1999). "The Role of Perceived Risk in the QualityValue Relationship: A Study in a Retail Environment," Journal of Retailing, 75(1): 77-105.

Tam, J.L.M. (2004). "Customer Satisfaction, Service Quality and Perceived Value: An Integrative Model," Journal of Marketing Management, 20: 897-917.

Teas, K. and Agarwal, S. (2000). "The Effects of Extrinsic Product Cues on Consumers' Perceptions of Quality, Sacrifice, and Value," Journal of the Academy of Marketing Science, 208(2): 278-290.

TUIK, Turkish Statistical Institute News Bulletin, (2011): "Household Information Technology Usage Study Results."

Turel, O., Serenko, A., and Bontis, N. (2007). "User Acceptance of Wireless Short Messaging Services Deconstructing Perceived Value," Information and Management, 44(1): 63-73.

Zait, A. and Bertea, P.E. (2011). "Methods for Testing Discriminant Validity," Management and Marketing, 9(2): 217-224.

Zeithaml, V. (1988). "Consumer Perceptions of Price, Quality and Value: A Means-End Model and Synthesis of Evidence," Journal of Marketing, 52: 2-22 


\section{APPENDIX}

\section{Table A.1: Measurement Items}

\section{Financial Risk Perception}

-Buying technology products from online retailers is a bad way to spend money

-When I buy technology products from online retailers, I would be concerned that the investment I would make would not be wise

-When I buy technology products from online retailers, I would be concerned that I really would not get my money's worth from this product

-I consider the Internet as a waste of money to purchase technology products

\section{Performance Risk Perception}

-There is a considerable chance that the technology products will be less than expected, when I buy through the internet.

-When I buy a technology product from online retailers, I become concerned that the product will not provide the level of benefits that I would be expecting

-Buying technology products from online retailers causes me to be concerned for how really dependable and reliable that product will be

\section{Perceived Sacrifice}

-The price charge of buying technology products from online retailers is high

-The time required to buy technology products from online retailers is high

-The effort that I must make to buy technology products from online retailers is high

-Buying technology products from online retailers is exhausting

\section{Perceived Relative Price}

-Online retailers selling technology products offer low prices

-Online retailers selling technology products have attractive offers

-Compared to other stores that offer products with similar features the prices of online retailers selling technology products are relatively low

Quality Perception

-Online retailers selling technology products offer me reliable products

-Online retailers selling technology products have dependable products

-Online retailers selling technology products have durable products

-Online retailers selling technology products offer me high quality products

\section{Value Perception}

-Online retailers selling technology products worth the money I spent

-Online retailers selling technology products worth the time I spent

-When I compare what I get for what I give, shopping from online retailers selling technology products offers good value

-Online retailers selling technology products meet my needs and expectations for a reasonable price -Overall, shopping from online retailers that sell technology products is a good buy

\footnotetext{
Willingness to Buy

-There is a considerable chance that I will purchase my next technology product through online retailers

-I recommend others to buy their technology products through online retailers

-The likelihood of purchasing technology products through online retailers is high

-My willingness to buy technology products through online retailers is high
} 